\title{
Efek Sinergis Kombinasi Ekstrak Rimpang Kunyit (Curcuma domestica Val.) dan Ampisilin Terhadap Escherichia coli Secara In Vitro
}

\author{
Kusmana P. Putra ${ }^{1}$, Djaja Rusmana ${ }^{2}$, Mariska Elisabeth ${ }^{3}$ \\ ${ }^{1}$ Fakultas Kedokteran Universitas Kristen Maranatha, Bandung \\ ${ }^{2}$ Departemen Mikrobiologi, Fakultas Kedokteran, Universitas Kristen Maranatha, Bandung \\ ${ }^{3}$ Departemen Patologi Anatomi, Fakultas Kedokteran, Universitas Kristen Maranatha, Bandung
}

\begin{abstract}
Abstrak
Escherichia coli pada kondisi tertentu dapat diobati dengan ampisilin. Namun ampisilin saat ini mulai ditinggalkan karena tingginya kasus $E$. coli yang resisten ampisilin. Salah satu cara untuk mengatasi masalah resistensi ini adalah dengan mengkombinasi ekstrak rimpang kunyit (ERK) dan ampisilin. Tujuan penelitian ini adalah untuk mengetahui efek antimikroba dan efek sinergis kombinasi ERK (Curcuma domestica Val.) dan ampisilin terhadap E. coli secara in vitro. Penelitian ini menggunakan desain uji esksperimental laboratorik sungguhan secara in vitro dengan metode agar diffusion. Data yang diperoleh disajikan dalam bentuk tabel dan dinalisis secara deskriptif. Dari hasil penelitian didapatkan bahwa konsentrasi ERK pada Muller-Hinton Agar (MHA) 165, 330, $660 \mu \mathrm{g} / \mathrm{ml}$ tidak didapatkan zona inhibisi terhadap E. coli. Persentasi peningkatan zona inhibisi MHA-ERK-ampisilin 165, 330, $660 \mu \mathrm{g} / \mathrm{ml}: 24,11 \%$; 38,79\%; 47,39\% lebih besar dibanding ampisilin tunggal. Simpulan dari penelitian ini adalah ekstrak rimpang kunyit $165 \mu \mathrm{g} / \mathrm{ml}, 330 \mu \mathrm{g} / \mathrm{ml}$, dan $660 \mu \mathrm{g} / \mathrm{ml}$ tidak memiliki efek antimikroba terhadap $E$. coli secara in vitro sedangkan kombinasi ekstrak rimpang kunyit dan ampisilin memiliki efek sinergis terhadap $E$. coli secara in vitro.
\end{abstract}

Kata Kunci: Escherichia coli; kunyit; Curcuma domestica val.; sinergis; antimikroba

\section{Synergistic Effect of Combination of Turmeric (Curcuma domestica Val.) Rhizome Extract and Ampicillin Against Escherichia coli In Vitro}

\begin{abstract}
Escherichia coli can be treated with ampisilin in certain condition. However, ampicilin is currently seldom being used because of a lot of case of ampicilin-resistant E. coli. One of ways to overcome this resistance problem with combining curcuma rhizome extract (CRE) and ampicilin. The aim of this study was to investigated antimicrobial susceptibility test and synergic effect of combination CRE (Curcuma domestica Val.) and ampisilin against E. coli in vitro. This study was a true experimental laboratory test deisgn in vitro with agar diffusion method. The data were presented in table form and analyzed descriptively. The result shows that there is no inhibitory zone of E. coli formed in CRE on Muller-Hinton Agar (MHA) at concentration 165, 330, $660 \mu \mathrm{g} / \mathrm{ml}$. The fold increases inhibition zone are observed for MHA-CRE-Ampisilin 165, 330, $660 \mu \mathrm{g} / \mathrm{ml}: 24,11 \% ; 38,79 \% ; 47,39 \%$ higher compared to ampicilin alone. The conclusion was curcuma rhizome extract (Curcuma domestica Val.) $165 \mu \mathrm{g} / \mathrm{ml}, 330 \mu \mathrm{g} / \mathrm{ml}$, and $660 \mu \mathrm{g} / \mathrm{ml}$ does not have antimicrobial effect against Escherichia coli in vitro while the combination of curcuma rhizome extract (Curcuma domestica Val.) and ampisilin does have synergic effect against Escherichia coli in vitro.
\end{abstract}

Keywords: Esherichia coli; curcuma; Curcuma domestica val.; synergic; antimicrobial

*KP: Penulis Koresponden, Email: kusmanapratamaputra@gmail.com 


\section{Pendahuluan}

Bakteri intestinal E. coli patogen merupakan penyebab diare terbanyak kedua setelah rotavirus. Menurut World Health Organization (WHO) Diare adalah penyebab kematian ke-dua pada anak dibawah usia 5 tahun (balita) setelah pneumonia atau penyakit infeksi saluran nafas lainnya. ${ }^{1,2}$ Di Indonesia angka kesakitan diare secara umum sebesar $6,8 \%$ dan usia balita adalah kelompok paling tinggi menderita diare sebesar $11 \%$ dengan episode serangan diare rata-rata 3,3× setiap tahun. ${ }^{3,4}$ Berdasarkan penelitian Caulfield et al. ${ }^{5}$ pada tahun 2004 di beberapa negara berkembang termasuk Indonesia, sekitar 52,5\% kematian pada anak disebabkan malnutrisi dan dehidrasi dan sekitar $60,7 \%$ akibat kematian tersebut berhubungan dengan diare.

Pengobatan utama infeksi $E$. coli umumnya tidak menggunakan antibiotik, penggunaanya sangat dibatasi hanya pada beberapa kondisi tertentu untuk mengurangi durasi dan tingkat keparahan dari gejala infeksi serta mengurangi risiko penularan penyakit. ${ }^{6}$ Antibiotik dapat diberikan pada infeksi $E$. coli penyebab diare bila penderita dalam kondisi sakit berat, disertai penyakit kronik, malnutrsi, imunokompromis, dan risiko sepsis. ${ }^{6,7}$ Salah satu antibiotik yang digunakan sebagai terapi infeksi E. coli adalah ampisilin.,

Penggunaan ampislin terhadap infeksi E. coli saat ini mulai ditinggalkan karena tingginya kasus infeksi $E$. coli yang resisten terhadap ampisilin. Escherichia coli dikatakan resisten terhadap ampisilin jika diameter zona inhibisi yang terbentuk kurang dari $13 \mathrm{~mm}$ berdasarkan standar interpretasi National Committee for Clinical Laboratory Standards (NCCLS). ${ }^{10} \quad$ Berdasarkan penelitian Jurnalis et al. ${ }^{11}$ pada tahun 2008, didapatkan resistensi kuman $E$. coli terhadap ampisilin sebesar 53,3\%, tetrasiklin 67,4\%, dan sulfametoksazole-trimetroprim $87 \%$.
Berdasarkan penelitian lain pada tahun 2019 dilaporkan peningkatan persentase spesies bakteri termasuk E. coli yang resisten terhadap ampisilin yaitu sebesar 30-50\% sejak awal antibiotik tersebut digunakan pada tahun $1960 .{ }^{12}$

Dengan meningkatnya strain $E$. coli yang resisten ampisilin, maka dibutuhkan suatu agen antimikroba yang dapat meningkatkan sensitivitas ampisilin. Saat ini para peneliti sudah mulai mencari solusi untuk meningkatkan sensitivitas antibiotik dengan mengembangkan strategi pengobatan melalui kombinasi antibiotik dengan produk herbal yang memiliki efek antimikroba, salah satunya adalah rimpang kunyit. ${ }^{12-15}$ Senyawa aktif yang terkandung dalam rimpang kunyit (Curcuma longa Linn.) seperti polifenol kurkumin, flavonoid, alkaloid, tanin dan minyak atsiri dapat berperan sebagai agen antimikroba terhadap beberapa bakteri patogen termasuk $E$. coli. ${ }^{14-}$ ${ }^{18}$ Banyak penelitian yang meneliti tentang aktivitas antimikroba rimpang kunyit ini dengan berbagai konsentrasi dan dilaporkan mempu menghambat pertumbuhan $E$. coli secara in vitro. ${ }^{14-19}$

Produk herbal yang dikombinasi dengan antibiotik sebagai terapi komplementer diharapkan mampu meningkatkan efek antimikroba satu sama lain (efek sinergis). ${ }^{12,19}$ Penelitian mengenai efek sinergis dari kombinasi herbal dan antibiotik pada penelitian Azucena et al. ${ }^{12}$ pada tahun 2019 didapatkan bahwa zat kurkumin tidak memiliki efek antimikroba, tetapi kombinasi kurkumin murni dan ampisilin memiliki efek sinergis terhadap $E$. coli dengan menggunakan metode agar diffusion..$^{12}$

Namun saat ini penelitian mengenai kombinasi ERK dan ampisilin belum ada. Alasan memilih rimpang kunyit karena mengandung senyawa aktifyang lebih banyak dibandingkan bagian lain dari tanaman kunyit seperti batang, daun, atau bunga serta cukup ekonomis dan mudah didapatkan di 
berbagai tempat di Indonesia. ${ }^{16-17}$ Penelitian ini adalah penelitian mengenai efek sinergis kombinasi ERK (Curcuma domestica Val.) dan ampisilin terhadap $E$. coli menggunakan konsentrasi ERK (Curcuma domestica Val.) pada beberapa konsentrasi.

\section{Bahan dan Cara}

Penelitian merupakan uji eksperimental laboratorik secara in vitro menggunakan metode agar diffusion dengan bahan uji kombinasi ERK dan ampisilin pada medium MHA (Mueller Hinton Agar) yang telah ditanam E. coli kemudian diameter zona inhibisi yang terbentuk diukur menggunakan jangka sorong manual dengan ketelitian 0,01 mm. Produk ERK yang digunakan dalam bentuk kapsul yang berisi serbuk terstandarisasi dari salah satu perusahaan herbal di Indonesia, sedangkan stok bakteri E. coli didapatkan dari koleksi Laboratorium Mikrobiologi Fakultas Kedokteran Universitas Kristen Maranatha, kemudian dilakukan identifikasi mikroba uji secara mikroskopis, makroskopis dan biokimia menggunakan RapID ONE system. Uji efek antimikroba dan uji efek sinergis dilakukan secara triplo.

Ekstrak yang digunakan serbuk ERK dengan komposisi $500 \mathrm{mg}$, setara $100 \mathrm{mg}$ kurkuminoid terstandarisasi atau $40 \mathrm{~g}$ kunyit segar per kapsul. Perhitungan konsentrasi larutan ERK sudah termasuk volume total pelarut media MHA-ERK yang dibuat secara triplo. Serbuk ERK dicampur dengan 2,3 $\mathrm{ml}$ dimetil sulfoksida(DMSO) per $10 \mathrm{mg}$ ERK dan disentrifugsi dengan vortex hingga homogen. Setelah itu larutan dimasukan kedalam botol masing-masing untuk setiap konsentrasi yang dicampurkan dengan MHA cair untuk membentuk MHA-ERK $165 \mu \mathrm{g} /$, $330 \mu \mathrm{g} / \mathrm{ml}$, dan $660 \mu \mathrm{g} / \mathrm{ml}$ dan dibuat secara triplo. Sedangkan pembuatan cakram ERK $165 \mu \mathrm{g} /, 330 \mu \mathrm{g} / \mathrm{ml}$, dan $660 \mu \mathrm{g} / \mathrm{ml}$ dibuat dengan merendam cakram steril dalam larutan ERK masing-masing konsentrasi. ${ }^{12}$

Suspensi $E$. coli dibuat dari biakan agar MacConkey yang telah diinkubasi selama 24 jam. Suspensi diambil dari koloni yang terpisah dengan morfologi yang sama. Kekeruhan suspensi untuk mencapai kerapatan yang setara dengan 0,5 standar McFarland.

Uji efek antimikroba dilakukan menggunakan metode disc diffusion Kirby Bauer pada media MHA, cakram ERK 165 $\mu \mathrm{g} /, 330 \mu \mathrm{g} / \mathrm{ml}$, dan $660 \mu \mathrm{g} / \mathrm{ml}$ diletakan pada permukaan MHA yang telah diinokulasi $E$. coli dengan metode spread plate, kemudian diinkubasi dalam suhu $37^{\circ} \mathrm{C}$ selama 24 jam. Diameter zona inhibisi yang terbentuk diukur menggunakan jangka sorong dengan ketelitian 0,01 mm.

Uji efek sinergis dilakukan mengunakan metode agar diffusion menggunakan MHA yang dicampur dengan ERK konsentrasi 165 $\mu \mathrm{g} /, 330 \mu \mathrm{g} / \mathrm{ml}$, dan $660 \mu \mathrm{g} / \mathrm{ml}$. Kemudian di inokulasi dengan $E$. coli menggunakan metode spread plate setelah itu diletakkan cakram ampisilin $10 \mu \mathrm{g}$ pada permukaan agar. MHA-ERK diinkubasi dalam suhu $37^{\circ} \mathrm{C}$ selama 24 jam. Diameter zona inhibisi yang terbentuk diukur menggunakan jangka sorong dengan ketelitian $0,01 \mathrm{~mm}$ dan persentase peningkatannya dihitung menggunakan rumus $\left(b^{2}-a^{2}\right) / a^{2} \times 100$. Dengan a adalah zona inhibisi ampisilin dan $b$ zona inhibisi kombinasi ERK dan ampisilin. Data yang diperoleh disajikan dalam bentuk tabel dan dilakukan analisis secara deskriptif.

\section{Hasil}

Dari uji efek antimikroba dan efek sinergis kombinasi ekstrak rimpang kunyit dan ampisilin metode agar diffusion didapatkan data seperti pada Tabel 1 sebagai berikut: 


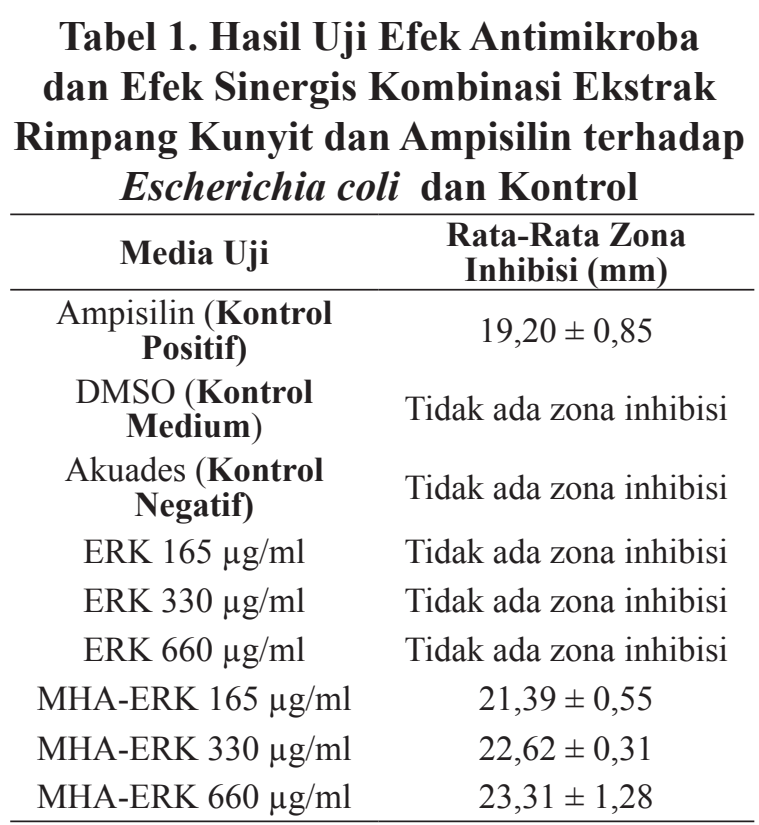

Keterangan: DMSO: dimetil sulfoksida

Berdasarkan data yang didapatkan pada penelitian menunjukkan bahwa ERK (Curcuma domestica Val.) $165 \mu \mathrm{g} / \mathrm{ml}, 330$ $\mu \mathrm{g} / \mathrm{ml}$, dan $660 \mu \mathrm{g} / \mathrm{ml}$ tidak didapatkan zona inhibisi terhadap E. coli.

Pada penelitian efek sinergis menggunakan kombinasi ERK dan ampisilin didapatkan zona inhibisi lebih besar dibanding kontrol ampisilin, seperti terlihat pada tabel 1. Persentasi peningkatan zona inhibisi kombinasi ERK dan ampisilin dapat dilihat pada Gambar 1 dengan hasil peningkatan MHA-ERK $165 \mu \mathrm{g} / \mathrm{ml}$ sebesar 24,11\%, MHA-ERK $330 \mu \mathrm{g} / \mathrm{ml}$ sebesar 38,79\%, dan MHA-ERK $660 \mu \mathrm{g} / \mathrm{ml}$ sebesar 47,39\%.

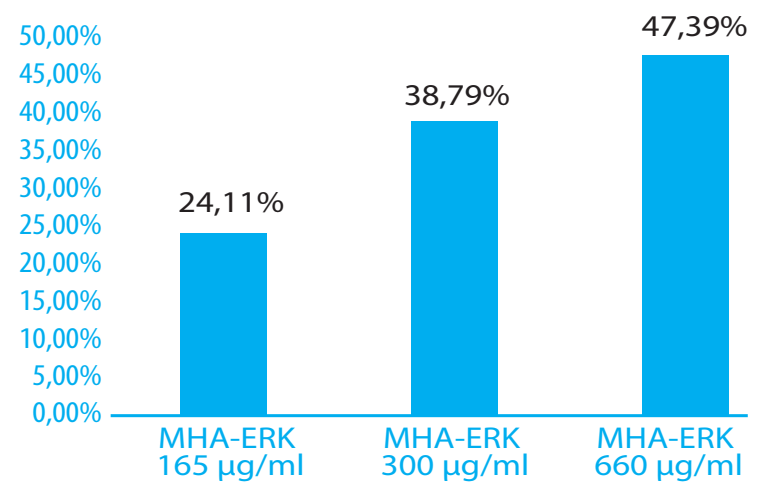

Gambar 1. Persentasi Peningkatan Sensitivitas Ampisilin Pada Kombinasi ERK dan Ampisilin terhadap E. coli

\section{Diskusi}

Pada penelitian didapatkan hasil bahwa ERK (Curcuma domestica Val.) $165 \mu \mathrm{g} / \mathrm{ml}$, $330 \mu \mathrm{g} / \mathrm{ml}$, dan $660 \mu \mathrm{g} / \mathrm{ml}$ tidak memiliki efek antimikroba terhadap E. coli. Hasil yang didapat pada penelitian ini dapat disebabkan karena faktor konsentrasi ERK $165 \mu \mathrm{g} / \mathrm{ml}, 330 \mu \mathrm{g} / \mathrm{ml}$ dan $660 \mu \mathrm{g} / \mathrm{ml}$ yang digunakan dalam penelitian terlalu kecil sehingga tidak cukup untuk menghambat pertumbuhan $E$. coli bila menggunakan metode disc diffusion dan juga dapat disebabkan karena diversivikasi atau sampel ekstrak rimpang kunyit yang digunakan berbeda dengan penelitian sebelumnya sehinga kandungan kimia nya pun ikut berbeda menyebabkan zona inhibisi yang didapatkan ikut berbeda. ${ }^{20,21}$ Hasil ini sejalan dengan penelitian Kumara et al. ${ }^{21}$ tahun 2019 yang menggunakan metode disc diffusion, ekstrak etanol kunyit (Curcuma longa Linn.) dengan konsentrasi $10 \%$, $20 \%$, 30\%, dan 40\% tidak didapatkan zona inhibisi terhadap Streptococcus mutans, kontrol positif vankomisin sebesar 23,8 mm. Penelitian Al-Daihan et al. ${ }^{13}$ menggunakan metode disc diffusion, ERK (Curcuma longa Linn.) $40 \mathrm{mg} /$ disc didapatkan zona inhibisi ekstrak metanol terhadap E. coli sebesar $12 \pm 0,65 \mathrm{~mm}$ dan etanol sebesar $11 \pm 0,55$ $\mathrm{mm}$ dengan kontrol positif kanamisin $30 \mu \mathrm{g} /$ disc sebesar $20 \pm 0,33 \mathrm{~mm}$. Penelitian Hosea (2018) menggunakan metode well diffusion dengan konsentrasi ERK (Curcuma longa Linn.) $\quad 0,2 \mathrm{~g} / \mathrm{ml}$ didapatkan zona inhibisi ekstrak etanol terhadap E. coli sebesar 25,33 $\mathrm{mm}$ dan ekstrak akuades sebesar 21,33 mm dengan kontrol positif tetrasiklin $0,5 \mathrm{~g} / \mathrm{ml}$ sebesar 29,67 mm. ${ }^{14}$ Penelitian Rini et al. ${ }^{20}$ di tahun 2018 menggunakan metode disc diffusion Kirby Bauer ekstrak etanol kunyit kering (Curcuma longa) konsentrasi 15\% didapatkan zona inhibisi terhadap E. coli sebesar 0,63 $\mathrm{mm}$ dan konsentrasi 100\% sebesar 1,13 mm. Hasil Penelitian, Al- 
Daihan et al. ${ }^{13}$, Hosea et al. ${ }^{14}$ dan Rini et al. ${ }^{20}$ menunjukkan bahwa ERK memiliki efek antimikroba terhadap E. coli tetapi tidak sebaik kontrol positif. ERK memiliki efek antimikroba yang lebih rendah dibanding kontrol positif terhadap E. coli dapat disebabkan oleh beberapa faktor seperti, faktor metode uji efek antimikroba, metode ekstraksi bahan uji, konsentrasi ekstrak, diversivikasi tanaman kunyit (perbedaan kandungan kunyit yang dapat dipengaruhi oleh lokasi tanaman, umur rimpang, proses pengeringan yang dapat mempengaruhi kualitas dan kuantitas kandungan kimia rimpang). ${ }^{20,21}$

Kombinasi ERK (Curcuma domestica Val.) dan ampisilin memiliki efek sinergis terhadap E. coli, hal ini sejalan dengan penelitian Azucena et al. ${ }^{12}$ yang meneliti kombinasi kurkumin 110, 220, $330 \mu \mathrm{g} /$ $\mathrm{ml}$ dan ampisilin terhadap E. coli. Dari penelitian tersebut diketahui bahwa kombinasi kurkumin murni $330 \mu \mathrm{g} / \mathrm{ml}$ dengan ampisilin dapat meningkatkan sensitivitas ampisilin $10 \mu \mathrm{g}$ terhadap E. coli sebesar $56,2 \%$ dengan zona inhibisi sebesar $11 \pm 1.0 \mathrm{~mm} .{ }^{12}$ Efek sinergis dapat terjadi karena ERK mengandung senyawa aktif seperti kurkumin, flavonoid, alkaloid, tannin, dan minyak atsriri yang berperan sebagai antibiotic resistance breaker (ARB) dengan mencegah atau mengatasi mekansime resistensi E. coli sehingga ampisilin dapat bekerja secara efektif. Kurkumin merupakan senyawa fenolik yang berperan paling akitf sebagai agen antimikroba dengan mekanisme kerja merusak integritas dinding sel dan membran sel pada bakteri baik Gram positif ( $S$. aureus) maupun Gram negatif (E. coli) hal ini disebabkan karena molekul kurkumin bersifat amphipathic dan lipophilic sehingga memungkinkan kurkumin masuk ke dalam lapisan membran luar lapis ganda (lipopolisakarida dan fosfolipid) kemudian berikatan dengan peptidoglikan menyebabkan peningkatan permeabilitas membran dan menyebabkan lisis pada sel bakteri sehingga ampisilin dapat mudah untuk masuk dan mencapai target PBP pada dinding sel $E$. coli, kurkumin juga diduga dapat menghambat modifikasi struktur target PBP pada E. coli seperti peranya dalam menghambat modifikasi PBP pada $S$. aureus, sehingga afinitas ampisilin terhadap PBP meningkat dan akhirnya meningkatkan efektifitas kerja ampisiln terhadap E. coli. ${ }^{22-}$ ${ }^{28}$ Disisi lain senyawa flavonoid diduga dapat meningkatkan akses ampisilin dengan meningkatkan permeabilitas sel dengan cara merusak integritas dan menghambat sintesis dinding sel dan membran menyebabkan ampisilin mudah masuk kedalam sel $E$. coli. Flavonoid juga dapat menghambat pembentukan protein. ${ }^{29-35}$ Senyawa alkaloid juga diduga dapat meningatkan akses ampisilin dengan meningkatkan permeabilitas membran, dan menghambat kerja enzim E. coli. $^{28,31,35}$ Senyawa alkaloid diduga dapat merusak integritas dinding sel E. coli, meningkatkan permeabilitas membran, dan kebocoran intrasel serta dapat mendenaturasi protein. ${ }^{28,31,35}$ Senyawa tannin diduga dapat meningkatkan akses ampisilin dengan cara merusak integritas dinding sel dan membran menyebabkan peningkatan permeabiltas sel terhadap ampisilin, serta menghambat fungsi kerja enzim (termasuk enzim ekstraseluler mikroba). ${ }^{31,36,38}$ Selain itu kandungan minyak atsiri juga dapat meningkatkan akses ampisilin dengan cara meningkatkan permeabilitas membran E. coli. ${ }^{17,38}$ Efek dari flavonoid dalam menghambat pembentukan protein, efek alkaloid dalam mendenaturasi protein dan menghambat pembentukan enzim, serta efek tannin dalam menghambat fungsi kerja enzim (termasuk enzim ekstraseluler mikroba) diduga berperngaruh terhadap tidak efektifnya peran enzim beta-laktamase E. coli untuk mendegradasi ampisilin..$^{31,34-38}$ Akhirnya dari kesemua itu didapatkan bahwa kombinasi ekstrak rimpang kunyit 
dan ampisilin memiliki efek sinergis untuk meningkatkan sensitivitas ampisilin terhadap E.coli. ${ }^{9,22,24,25,37-38}$

\section{Kesimpulan}

Ekstrak rimpang kunyit (Curcuma domestica Val.) $165 \mu \mathrm{g} / \mathrm{ml}, 330 \mu \mathrm{g} / \mathrm{ml}$, dan $660 \mu \mathrm{g} / \mathrm{ml}$ tidak memiliki efek antimikroba terhadap Escherichia coli secara in vitro.

Kombinasi ekstrak rimpang kunyit (Curcuma domestica Val.) dan ampisilin memiliki efek sinergis terhadap Escherichia coli secara in vitro. Kombinasi ekstrak rimpang kunyit (Curcuma domestica Val.) $165 \mu \mathrm{g} / \mathrm{ml}$ dan ampisilin memiliki zona inhibisi yang lebih besar dibanding ampisilin.

\section{Daftar Pustaka}

1 World Health Organization (WHO): Dirrhoeal Disease. Diunduh dari https://www.who.int/ news-room/fact-sheets/detail/diarrhoeal-disease 3 September 2020.

2. Centre for Disease Control and Prevention. Diarrhea: Common Illness, Global Killer. Centers Dis Control Prev. 2012;1-4.

3. Riskesdas K. Hasil Utama Riset Kesehata Dasar (RISKESDAS). J Phys A Math Theor. 2018;44(8):1-200.

4. Susanti WE, Sunarsih E. Determinan kajadian diare pada anak balita di indonesia (analisis lanjut data sdki 2012) Jurnal Ilmu Kesehatan Masyarakat Angka kematian bayi dan anak ting. 2016;7:64-72.

5. Caulfield LE, de Onis M, Blössner M, Black RE. Undernutrition as an underlying cause of child deaths associated with diarrhea, pneumonia, malaria, and measles. Am J Clin Nutr. 2004;80(1):193-8.

6. Guarino A, Bruzzese E, Giannattasio A. Antibiotic treatment of acute gastroenteritis in children. F1000Research. 2018;7:1-10.

7. Doe WF, Barr GD. Acute diarrhoea in adults. Aust Fam Physician. 1981;10(6):438-46.

8. Kaushik D, Mohan M, Borade DM, Swami OC. Ampicillin: Rise fall \& resurgence. J Clin Diagnostic Res. 2014;8(5):10-2.

9. Diniz-Santos DR, Silva LR, Silva N. Antibiotics for the empirical treatment of acute infectious diarrhea in children. Brazilian J Infect Dis. 2006;10(3):217-27.
10. Thakre R, Eqbal S, Dwivedi A, Jain S. A new method for the development of Escherichia coli resisitant against antibiotic ampicillin. 2018. diunduh dari https://businessdocbox.com/ Biotech_and_Biomedical/90637908-A-newmethod-for-the-development-of-escherichiacoli-resisitant-against-antibiotic-ampicillin.html 4 September 2020.

11. Jurnalis YD, Sayoet Y, Aslinar A. Pola resistensi kuman penyebab diare terhadap antibiotika. Maj Kedokt. 2008;33.

12. Azucena RCI, Roberto CLJ, Martin ZR, Rafael CZ, Leonardo HH, Gabriela TP, et al. Drug susceptibility testing and synergistic antibacterial activity of curcumin with antibiotics against enterotoxigenic Escherichia coli. Antibiotics. 2019;8(2).

13.Al-Daihan S,Al-Faham M,Al-shawi N,Almayman $\mathrm{R}$, Brnawi A, zargar S, et al. Antibacterial activity and phytochemical screening of some medicinal plants commonly used in Saudi Arabia against selected pathogenic microorganisms. J King Saud Univ - Sci. 2013;25(2):115-20.

14. Hosea ZY, Kator L, Rhoda EH. Phytochemical properties and antimicrobial activities of aqueous extract of Curcuma longa (turmeric) rhizome extract. Asian J Res Crop Sci. 2018;2(1):1-8.

15. Cobra LS, Amini HW, Putri AE. Skirining fitokimia ekstrak sokhletasi rimpang kunyit (Curcuma longa) dengan pelarut etanol $96 \%$. J Ilm Kesehat Karya Putra Bangsa. 2019;1(1):12-7.

16. Oghenejobo M. Antibacterial evaluation, phytochemical screening and ascorbic acid assay of turmeric (Curcuma longa). MOJ Bioequivalence Bioavailab. 2017;4(2):232-9.

17. Abdullatif. Daya hambat ekstrak rimpang kunyit (Curcuma domestica Val.) terhadap pertumbuhan Staphylococcus aureus dan Staphylococcus epidermidis secara in vitro. Semarang: Program Studi D IV Analisis Kesehatan Fakultas Ilmu Keperawatan dan Kesehatan, Universitas Muhammadiyah Semarang. 2016. Skripsi

18. Ramadhani P. Hambat ekstrak etanol rimpang kunyit (Curcuma domestica V.) terhadap pertumbuhan bakteri Staphylococcus aureus secara in vitro. 2017;6(3):590-5.

19. Laishram S, Pragasam A, Bakthavatchalam Y, Veeraraghavan B. An update on technical, interpretative and clinical relevance of antimicrobial synergy testing methodologies. Indian J Med Microbiol. 2017;35(4):445-68.

20. Rini CS, Rohmah J, Widyaningrum LY. Efektivitas Kunyit (Curcuma longa Linn) terhadap Esherichia coli dan Bacillus subtilis. Medicra J Med Lab Sci. 2018;1(1):1. 
21. Kumara INC, Sri Pradnyani IGA, Sidiarta IGAFN. Uji efektivitas ekstrak kunyit (Curcuma longa) terhadap daya hambat pertumbuhan bakteri Streptococcus mutans. Intisari Sains Medis. 2019;10(3):462-7.

22. Tyagi P, Singh M, Kumari H, Kumari A, Mukhopadhyay K. Bactericidal activity of curcumin $\mathrm{I}$ is associated with damaging of bacterial membrane. PLoS One. 2015;10(3):115.

23. Teow SY, Liew K, Ali SA, Khoo ASB, Peh SC. Antibacterial action of curcumin against Staphylococcus aureus: A Brief Review. J Trop Med. 2016;2016(November).

24. Ardhany SD, Puspitasari Y, Meydawati Y, Novaryatiin S. Efektivitas antibakteri senyawa kurkumin terhadap foodborne bacteria: Tinjauan Curcuma longa untuk mengatasi resistensi antibiotik. J Sains Kesehat. 2019: 2(2): 122-8.

25. Kai K, Bi W, Bo Y, Ye Y, Zhang D. Curcumin-A Review of Its Antibacterial Effect. Biomed J Sci Tech Rec. 2020;19585-7.

26. Halim SW, Wihanto L, Sutandhio S. Antibacterial effect of Curcuma domestica ethanolic extract on group a Streptococcus $\beta$ hemoyticus. J Widya Medica Junior.2019:1(3).159-64.

27. Moghadamtousi S, Abdul Kadir H, Hassandarvish P, Tajik H, Abubakar S, Zandi K. A review on antibacterial, antiviral, and antifungal activity of curcumin. Biomed Res Int. 2014;2014.

28. Butarbutar R: Uji Aktivitas antibakteri ekstrak etanol buah attarasa (Litsea cubeba (Lour.) Pers.) terhadap bakteri Staphylococcus aureus dan Eschericia coli. Medan: Program Studi Sarjana Farmasi Fakultas Farmasi dan Kesehatan Umum Institut Kesehatan Helvetia Medan. 2019. Skripsi

29. Sastika AR, Mulyani S. Ekstrak metanol dan etanol daun sidaguri (Sida rhombifilia 1.) menghambat pertumbuhan bakteri Klebsiella pneumonia tetapi tidak terhadap Staphylococcus aureus. Proceeding Biology Education Conference. 2012;9(6).560-3.

30. Othman L, Sleiman A, Abdel-massih RM. Antimicrobial activity of polyphenols and alkaloids in Middle Eastern plants. 2019; May 15;10:911.

31. Cushnie TPT, Lamb AJ. Recent advances in understanding the antibacterial properties of flavonoids. Int $\mathrm{J}$ Antimicrob Agents. 2011;38(2):99-107.

32. Heinrich M, Barnes J, Gibbons S, Williamson EM. Farmakognosis dan Fitoterapi. Ahli bahasa: Syarief WR et al; Ed Edisi Bhs Indonesia: Hadinata AH. Farmakognosi Dan Fitoterapi:.2010 Jakarta: EGC. 2009

33. Sundari D dan Winarmo MW. Informasi tumbuhan obat sebagai anti jamur. 2021. Cermin Dunia Kedokt, 130. 28-30

34. Cushnie TPT, Cushnie B, Lamb AJ. Alkaloids: An overview of their antibacterial, antibioticenhancing and antivirulence activities. Int $\mathrm{J}$ Antimicrob Agents. 2014;44(5):377-86.

35. Stefanović OD. Synergistic Activity of Antibiotics and Bioactive Plant Extracts: A Study Against Gram-Positive and GramNegative Bacteria [Internet]. in Kirmusaoğlu S. Bacterial Pathogenesis and Antibacterial Control. InTech. 2018; https://www.intechopen. com/chapters/57789

36. Scalbert A. Antimicrobial properties of tannins. Phytochemistry. 1991;30(12):3875-83.

37. LIPI. Berita Biologi. Vol. 9, Jurnal Ilmiah Nasional. Pusat Penelitian Biologi - LIPI; 2008. $1-8 \mathrm{p}$.

38. Zeng X, Lin J. Beta-lactamase induction and cell wall metabolism in Gram-negative bacteria. Front Microbiol. 2013; 22;4:128. 